\title{
Congenital Hyperthyroidism Caused by a Solitary Toxic Adenoma Harboring a Novel Somatic Mutation (Serine281 $\rightarrow$ Isoleucine) in the Extracellular Domain of the Thyrotropin Receptor
}

\author{
Peter Kopp, ${ }^{\star}$ Sarah Muirhead, ${ }^{\ddagger}$ Nathalie Jourdain, ${ }^{\ddagger}$ Wen-Xia Gu, ${ }^{\star}$ J. Larry Jameson, ${ }^{*}$ and Celia Rodd ${ }^{\ddagger}$ \\ *Center for Endocrinology, Metabolism and Molecular Medicine, Northwestern University, Chicago, IL 60611; and ${ }^{\ddagger}$ Montreal Children’s \\ Hospital, McGill University, Montreal PQ H3H 1P3, Canada
}

\begin{abstract}
Activating somatic mutations in the thyrotropin (TSH) receptor have been identified as a cause of hyperfunctioning thyroid adenomas, and germline mutations have been found in familial nonautoimmune hyperthyroidism and sporadic congenital hyperthyroidism. All mutations reported to date have been located in the transmembrane domain. We now report an example of an activating mutation in the extracellular, TSH-binding domain, found in a male infant with congenital hyperthyroidism due to a toxic adenoma. The pregnancy was remarkable for fetal tachycardia. Scintigraphic studies demonstrated a large nodule in the right lobe, and a hemithyroidectomy was performed at the age of $2 \mathrm{yr}$. Direct sequencing of the TSH receptor gene revealed a mutation in one allele resulting in a substitution of serine 281 by isoleucine (Ser281 $\rightarrow$ Ile) in the extracellular domain. The mutation was restricted to the adenomatous tissue. Expression of the Ser281 $\rightarrow$ Ile mutation in vitro revealed an increase in basal cAMP levels. Affinity for TSH was increased by the mutation. These findings demonstrate that activating mutations can also occur in the extracellular domain of the TSH receptor, and support a model in which the extracellular domain serves to restrain receptor function in the absence of TSH or antibody-induced conformational changes. (J. Clin. Invest. 1997. 100:1634-1639.) Key words: toxic adenoma - TSH receptor • gene mutation • congenital hyperthyroidism
\end{abstract}

\section{Introduction}

The thyrotropin $(\mathrm{TSH})^{1}$ receptor, a member of the seven transmembrane $\mathrm{G}$ protein-coupled receptors, can be constitutively activated by a large number of point mutations which re-

Address correspondence to Dr. Peter Kopp, Center for Endocrinology, Metabolism and Molecular Medicine, Northwestern University, Tarry 15, 303 East Chicago Avenue, Chicago, IL 60611. Phone: 312503-1610; FAX: 312-908-9032; E-mail: petekopp@merle.acsn.nwu.edu S. Muirhead's current address is Children's Hospital of Eastern Ontario, University of Ottawa, Ottawa K1N 6N5, Canada.

Received for publication 18 April 1997 and accepted in revised form 18 July 1997.

1. Abbreviations used in this paper: PTU, propylthiouracil; TSH, thyrotropin.

J. Clin. Invest.

(C) The American Society for Clinical Investigation, Inc. 0021-9738/97/09/1634/06 \$2.00

Volume 100, Number 6, September 1997, 1634-1639

http://www.jci.org sult in increased basal cAMP levels (1). Chronic stimulation of the cAMP cascade by activated receptors results in enhanced proliferation and function of thyroid follicular cells $(2,3)$. A wide variety of activating somatic mutations have been found in toxic adenomas (references 4-9 and our unpublished results). The prevalence of these mutations in toxic adenomas varies between 2.5 and $80 \%(7,10)$, a finding which might, in part, be influenced by differences in iodine intake, sampling technique, and methodological approach $(11,12)$. Germline TSH receptor mutations have also been found in nonautoimmune familial hyperthyroidism $(13,14)$, and de novo germline mutations can cause sporadic congenital hyperthyroidism (15-17).

These rare cases of nonautoimmune congenital hyperthyroidism due to TSH receptor mutations must be differentiated from the much more frequent and transient form of hyperthyroidism that occurs in the offspring of mothers with a history of autoimmune thyroid disease. In these infants, hyperthyroidism is caused by transplacental passage of stimulating TSH receptor autoantibodies (18-20).

Solitary hyperfunctioning thyroid nodules are extremely rare in childhood, and only a few cases have been reported (21-24). In this study, we present a boy with congenital hyperthyroidism caused by a large solitary adenoma. Direct DNA sequencing revealed an activating mutation in the carboxy-terminal part of the extracellular domain.

\section{Methods}

\section{Case report}

The boy was born at $36 \mathrm{wk}$ of gestation to a healthy 35 -yr-old mother ( 3 para, 1 abortus) after an uneventful delivery. The birth weight was 3,150 grams (25th percentile), length was $51 \mathrm{~cm}$ (50th percentile), and the head circumference was $35 \mathrm{~cm}$ (50th percentile). The pregnancy was remarkable for fetal tachycardia of 180-200 beats per minute (bpm) starting in the 35th wk. The baby was noted to have a prominent stare, but no signs of exophthalmos. After day 10, the baby was noted to be increasingly irritable and had persistent resting tachycardia. His weight gain was normal, and there was no history of diarrhea. At $36 \mathrm{~d}$ of age, he was transferred to a tertiary care center where he was still persistently tachycardic at 170-200 bpm, with moderate systolic hypertension $(105 / 55 \mathrm{mmHg}$; 95 th percentile at 1 mo for systolic pressure $=103 \mathrm{mmHg}$ ). He had a grade II/VI systolic ejection murmur but no signs of congestive heart failure. He was jittery and irritable. No goiter was detected on physical exam, but hyperthyroidism was confirmed at the time of transfer with a markedly elevated total T4 of $365 \mathrm{nmol} /$ liter (86-193), a total T3 of $10 \mathrm{nmol} /$ liter (1-4), and a suppressed TSH $<0.5 \mathrm{IU} /$ liter $(0.5-5.5)$. Retrospectively, the blood sample obtained at the neonatal screening on day 7 was also found to contain clearly hyperthyroid values, with an unmeasurable TSH, a total T4 of $348 \mathrm{nmol} /$ liter and a free T4 of $75.9 \mathrm{nmol} /$ liter (9-27). He did not have craniosynostosis. His bone age was advanced to $4 \mathrm{mo}$ at $5 \mathrm{wk}$ of age.

Initially, the patient was treated with Lugol's solution, propanolol, and propylthiouracil (PTU). At $10 \mathrm{wk}$, he became hypothyroid, and the PTU was discontinued. However, signs of hyperthyroid- 
ism recurred within 4-6 d, and T4 was $334 \mathrm{nmol} /$ liter, T3 was 9.8 $\mathrm{nmol} /$ liter, and TSH was undetectable. He relapsed on two subsequent attempts to wean his medication. At 6 mo, his bone age had advanced to $15 \mathrm{mo}$

The mother's history was negative for any thyroid disease, and she did not have a goiter. The family history was positive for autoimmune hyperthyroidism in a paternal aunt, and autoimmune hypothyroidism in a paternal aunt and great aunt. The mother's thyroid function tests $36 \mathrm{~d}$ postpartum were normal. Both the mother and baby had undetectable levels of antimicrosomal and antithyroglobulin an-

A

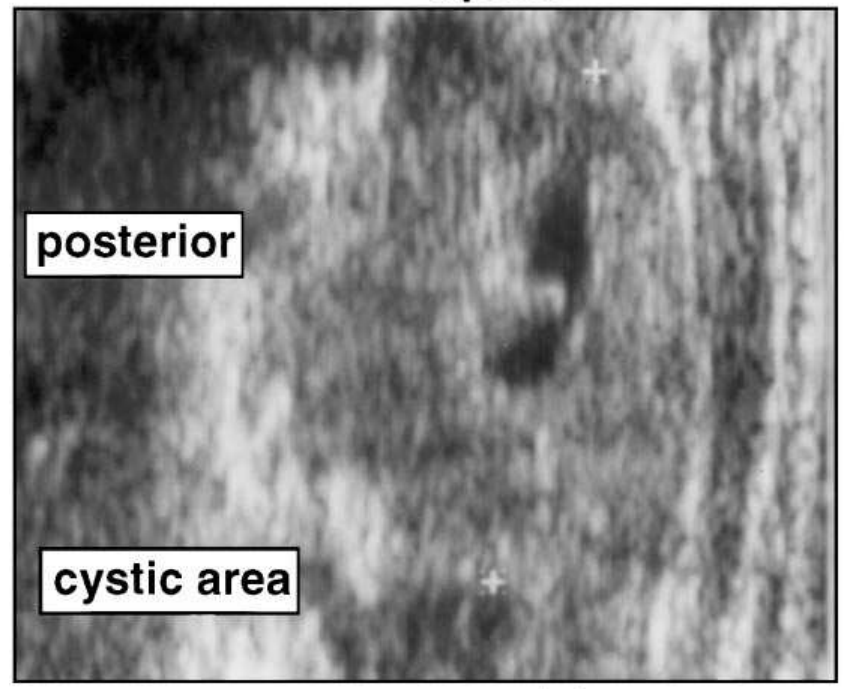

caudal

B

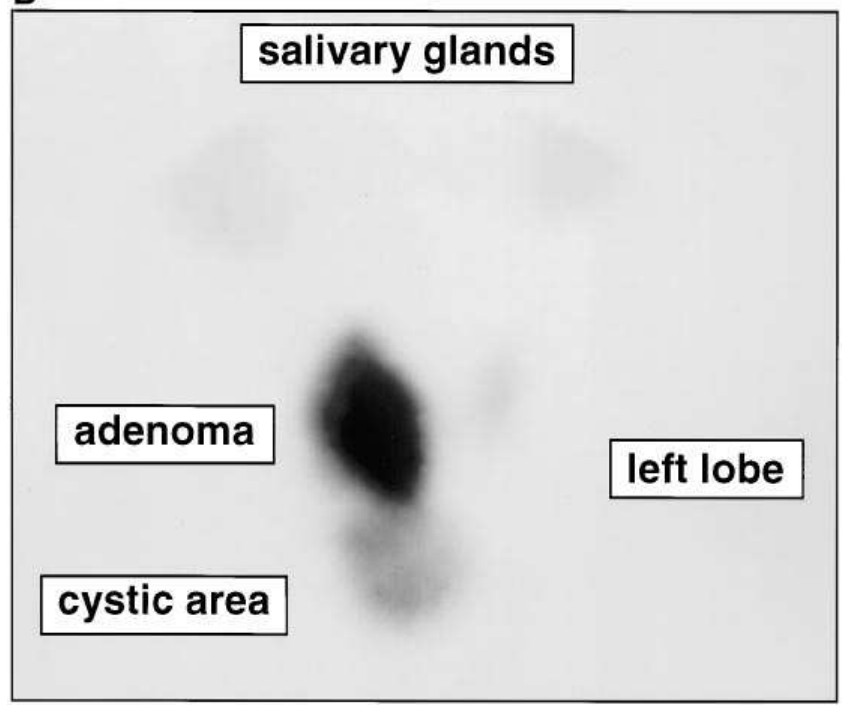

Figure 1. (A) Sagittal ultrasonography of the right thyroid lobe. A nodular lesion of $\sim 3.1 \times 2.2 \times 2 \mathrm{~cm}$ containing several small cystic areas accounts for the major part of the right lobe. A cystic area is also present in the caudal part of the right lobe. The ultrasonography of the left lobe was normal in appearance and size. $(B)$ Technetium scan of the thyroid gland. The tracer uptake is concentrated in the upper right lobe, which is enlarged $(\sim 3.1 \times 1.9 \mathrm{~cm})$. The diminished uptake in the caudal part of the right lobe corresponds to the cystic area observed in the ultrasonography. The left lobe shows only minimal tracer uptake, suggesting suppression by the hyperfunctioning tissue. tibodies, and insignificant levels of TSH receptor antibodies, with values of 2.0 and $2.4 \mathrm{U} /$ liter, respectively, on day 38 (normal $<10$ ). Repeated assessments of TSH receptor antibodies remained negative.

Given the persistence of the hyperthyroidism and the absence of any known antithyroid antibodies in his serum, further investigations were initiated to determine the cause of hyperthyroidism. An ultrasound of the thyroid demonstrated a very large right lobe $(3.1 \times 2.2 \times$ $2 \mathrm{~cm}$ ) containing several cystic areas (Fig. $1 A$ ). The left lobe was normal in appearance. A technetium scan documented that the tracer uptake was concentrated in the upper right lobe (Fig. $1 \mathrm{~B}$ ). The right lobe was larger than normal and measured $3.1 \times 1.9 \mathrm{~cm}$. The left lobe was normal in size and had diminished tracer uptake. Clinically, the right lobe was enlarged, and the right upper pole was palpable as a discrete nodule.

At the age of $2 \mathrm{yr}$, after being well controlled on PTU, the boy underwent a hemithyroidectomy to remove the hyperfunctioning nodule. The resected right lobe measured $2.4 \times 1.5 \times 1.8 \mathrm{~cm}$. Macroscopically, it consisted of a large, well-encapsulated nodule that comprised the majority of the lobe. Light microscopy demonstrated that the nodule was composed of multiple smaller nodules consisting of follicles of varying sizes with irregular contours and hyperplastic epithelium (Fig. 2). The colloid in these follicles was of varying amounts and showed signs compatible with active resorption. There was no lymphocytic infiltration. The thyroid tissue in the nonadenomatous regions of the right lobe and from the isthmus demonstrated a microfollicular pattern.

Postoperatively, after the PTU was discontinued, the patient remained euthyroid. He is now 3 yr of age, euthyroid without medication, and his psychomotor development is normal.

\section{Genetic studies}

DNA sequencing. DNA was extracted from the hyperfunctioning nodule and from normal tissue of the isthmus as well as from peripheral leukocytes from the patient and from peripheral leukocyte cells of his parents. Exon 10 of the TSH receptor and exons 8 and 9 of Gs $\alpha$ were amplified with primers reported elsewhere $(4,25)$, and submitted to direct sequencing. After demonstration of the wild-type sequence in these segments of the respective genes, the exons encoding the extracellular domain of the TSH receptor were amplified and submitted to direct sequencing (for primer sequences see reference 26). The sense primers contained a $-21 \mathrm{M} 13$-tag, and the antisense primer contained an M13-tag. Direct sequencing was performed using FS AmpliTaq DNA polymerase with an ABI prism ${ }^{\circledR}$ dye primer cycle sequencing kit (Applied Biosystems, Inc., Foster City, CA) fol-

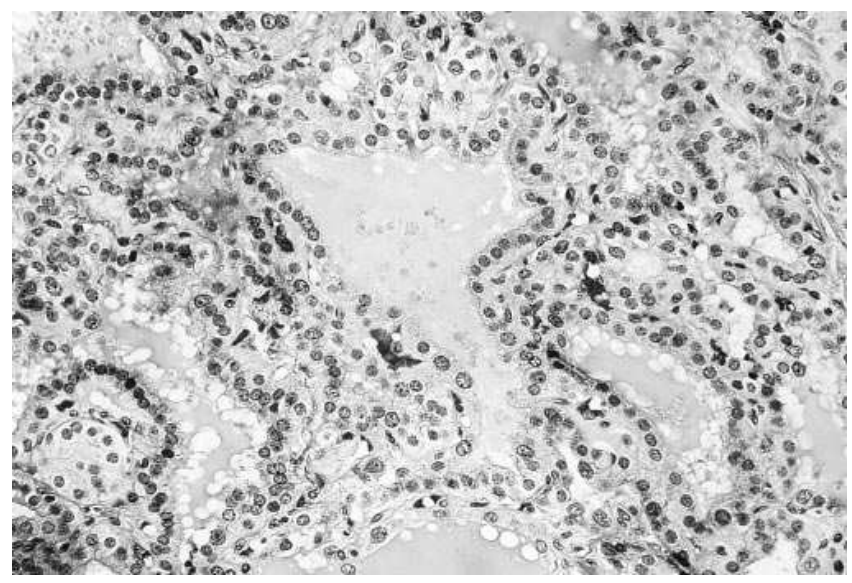

Figure 2. Light microscopy of an area of the resected adenoma from the right lobe. The follicular epithelium is hyperplastic and displays irregular contours. The colloid seems to be actively resorbed. Lymphocytic infiltration is absent. (Hematoxylin-phloxine-saffron stain; $\times 200$ ). 
lowing the protocol of the supplier. Sequencing products were analyzed on a sequencer (model 373A; Applied Biosystems).

Mutagenesis. The wild-type TSH receptor cDNA in the expression vector $\mathrm{pSVL}$, and a $\mathrm{pSVL}-\mathrm{TSH}$ receptor construct containing the activating mutation Phe631 $\rightarrow$ Leu were gifts from Prof. Gilbert Vassart (Institut de recherche interdisciplinaire, Université libre de Bruxelles, Brussels, Belgium). Construction of the Ser281 $\rightarrow$ Ile construct was performed using an overlap extension methodology with Pfu polymerase (Stratagene Inc., La Jolla, CA) (27). After transformation of the wild-type construct in dem negative DM1 Escherichia coli (GIBCO BRL, Gaithersburg, MD), a Bst98.I-BalI fragment was replaced with an insert containing the mutation. The final construct was verified by direct DNA sequencing.

Transient expression, cAMP and luciferase assays, and determination of inositol phosphates. TSA cells were maintained in DME containing $10 \%$ FBS, penicillin $(100 \mathrm{U} / \mathrm{ml})$, and streptomycin $(100 \mu \mathrm{g} /$ $\mathrm{ml})$. Cells were split into 12-well plates the day before transfection and grown to $80 \%$ confluency. Transfection was performed using the calcium-phosphate method. $0.5 \mu \mathrm{g}$ of plasmids containing the wildtype or mutant TSH receptor cDNAs (Phe631 $\rightarrow$ Leu, Ser281 $\rightarrow$ Ile) was transfected per well. The empty pSVL vector was included as negative control. All experiments were performed in triplicate in at least three independent experiments. Groups were compared by ANOVA.

For luciferase assays, $0.5 \mu \mathrm{g}$ of a cAMP-dependent reporter plasmid containing $-846 \mathrm{bp}$ of the human glycoprotein hormone $\alpha$-gene promoter fused to the luciferase gene was cotransfected. Cells were harvested after $48 \mathrm{~h}$ for luciferase assays, cAMP- or TSH-binding studies. Luciferase assays were performed as described previously (28).

After stimulation with $100 \mathrm{mU} / \mathrm{ml}$ bovine TSH (Sigma Chemical Co., St. Louis, MO) for $30 \mathrm{~min}$ in PBS with $0.5 \mathrm{mM} 3$-isobutyl-1-methylxanthine, the medium was removed, and ice-cold $95 \%$ ethanol was added to the cells (29). The cell extracts were dried under vacuum, and cAMP was determined with an enzyme immunoassay (Biotrak; Amersham Corp., Arlington Heights, IL).

For determination of inositol phosphates, the cells were incubated with $4 \mu \mathrm{Ci} / \mathrm{ml}^{3} \mathrm{H}$-myoinositol (American Radiolabeled Chemicals, St. Louis, MO) in DME supplemented with 3\% FBS. The medium was removed $24 \mathrm{~h}$ later and replaced by PBS containing $20 \mathrm{mM}$ $\mathrm{LiCl}$ for $30 \mathrm{~min}$ at $37^{\circ} \mathrm{C}$. Cells were then treated with $100 \mathrm{mU} / \mathrm{ml}$ bovine TSH for $30 \mathrm{~min}$. After removal of the medium, ice-cold $0.4 \mathrm{M}$ $\mathrm{HClO}_{4}$ was added. ${ }^{3} \mathrm{H}$-labeled inositol phospates were isolated by AG1-X8 resin chromatography (30), and measured in a scintillation counter.

TSH binding. Binding of TSH to the wild-type and mutated receptors in transfected TSA cells was measured using ${ }^{125} \mathrm{I}$-labeled bo- vine TSH (31). Cells were incubated for $2 \mathrm{~h}$ at $22^{\circ} \mathrm{C}$ in $400 \mu \mathrm{l}$ assay buffer $(222 \mathrm{mM}$ sucrose-supplemented $\mathrm{NaCl}$-free $\mathrm{HBSS}$ with $0.5 \%$ BSA and $20 \mathrm{mM}$ Hepes, pH 7.4) containing $2-4 \times 10^{4} \mathrm{cpm}(45 \mu \mathrm{Ci})$ ${ }^{125}$ I-bovine TSH (a gift from BRAHMS Diagnostica GmbH, Berlin, Germany) in the presence of increasing amounts of unlabeled TSH (provided by the National Hormone and Pituitary Program, National Institutes of Health). Cells were washed four times with assay buffer and solubilized in $1 \mathrm{~N} \mathrm{NaOH}$. Bound radioactivity was measured, and specific binding was calculated by subtracting nonsaturable binding in the presence of $10^{-7} \mathrm{M}$ unlabeled TSH.

\section{Results}

Identification of a mutation in the TSH receptor gene. A transversion of $\mathrm{G}$ to $\mathrm{T}$ was identified in the extracellular segment of the receptor in DNA from adenomatous tissue, but not in DNA from peripheral blood cells of the patient, indicating a somatic mutation in exon 9 (Fig. 3). The patient was heterozygous for the mutation resulting in a substitution of serine (AGC) by isoleucine (ATC) at position 281 in one allele (Fig. 3 ). Both parents showed only the wild-type sequence at this location.

Functional properties of the TSH receptor mutation Ser$281 \rightarrow$ Ile. The functional consequences of the mutation Ser$281 \rightarrow$ Ile were studied in transiently transfected TSA cells. Empty vector, the wild-type receptor, and a known constitutively activating mutation (Phe631 $\rightarrow$ Leu) (15) were included as controls.

Luciferase activity was measured $48 \mathrm{~h}$ after transfection of TSA cells with empty vector or with $\mathrm{pSVL}$ vectors containing wild-type or mutant TSH receptor constructs (Fig. 4, $A$ and $B$ ). Consistent with previous studies using this methodological approach (28), the wild-type TSH receptor displayed constitutive basal activity in comparison with the empty vector. Basal cAMP-dependent luciferase activity in TSA cells transfected with increasing amounts of mutant constructs was 2.6 $(\mathrm{F} 631 \mathrm{~L} \rightarrow$ Leu $)$ to 6.1 times higher $($ Ser281 $\rightarrow$ Ile) than in cells transfected with the wild-type receptor (Fig. $4 \mathrm{~B}$ ). The response to TSH was retained by the mutant receptors.

Cells transfected with the mutant receptors displayed an approximately eightfold increase of basal cAMP levels after 30 min in comparison with the wild-type receptor (Fig. 4 C). Basal

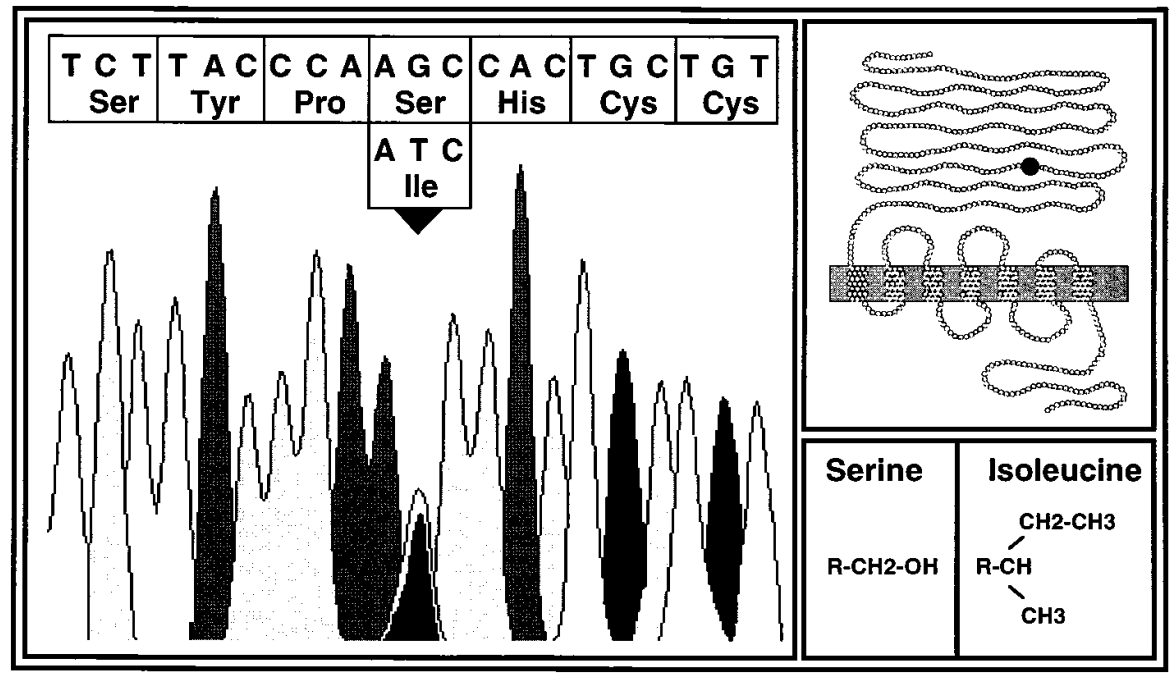

Figure 3. Nucleotide and amino acid sequence of part of exon 9 encoding the carboxy terminus of the extracellular domain of the TSH receptor. A heterozygous transversion of $\mathrm{G}$ to $\mathrm{T}$ in codon 281 results in the substitution of serine $(A G C)$ by isoleucine $(A T C)$ in the mutated allele. (Numbering of residues begins at the start codon). The relative position of the mutation in the receptor and the structure of the amino acid side chains is shown on the right. 


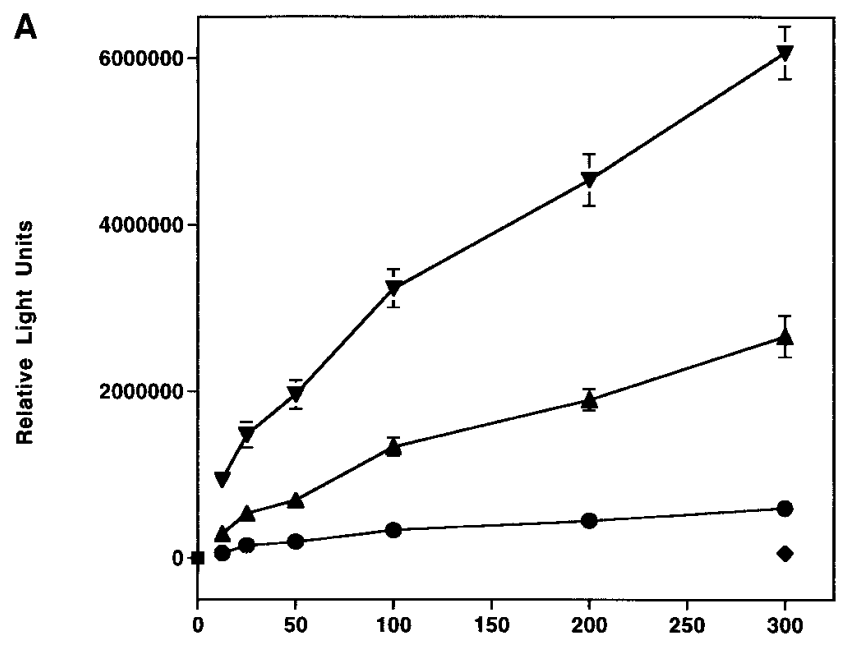

ng DNA transfected
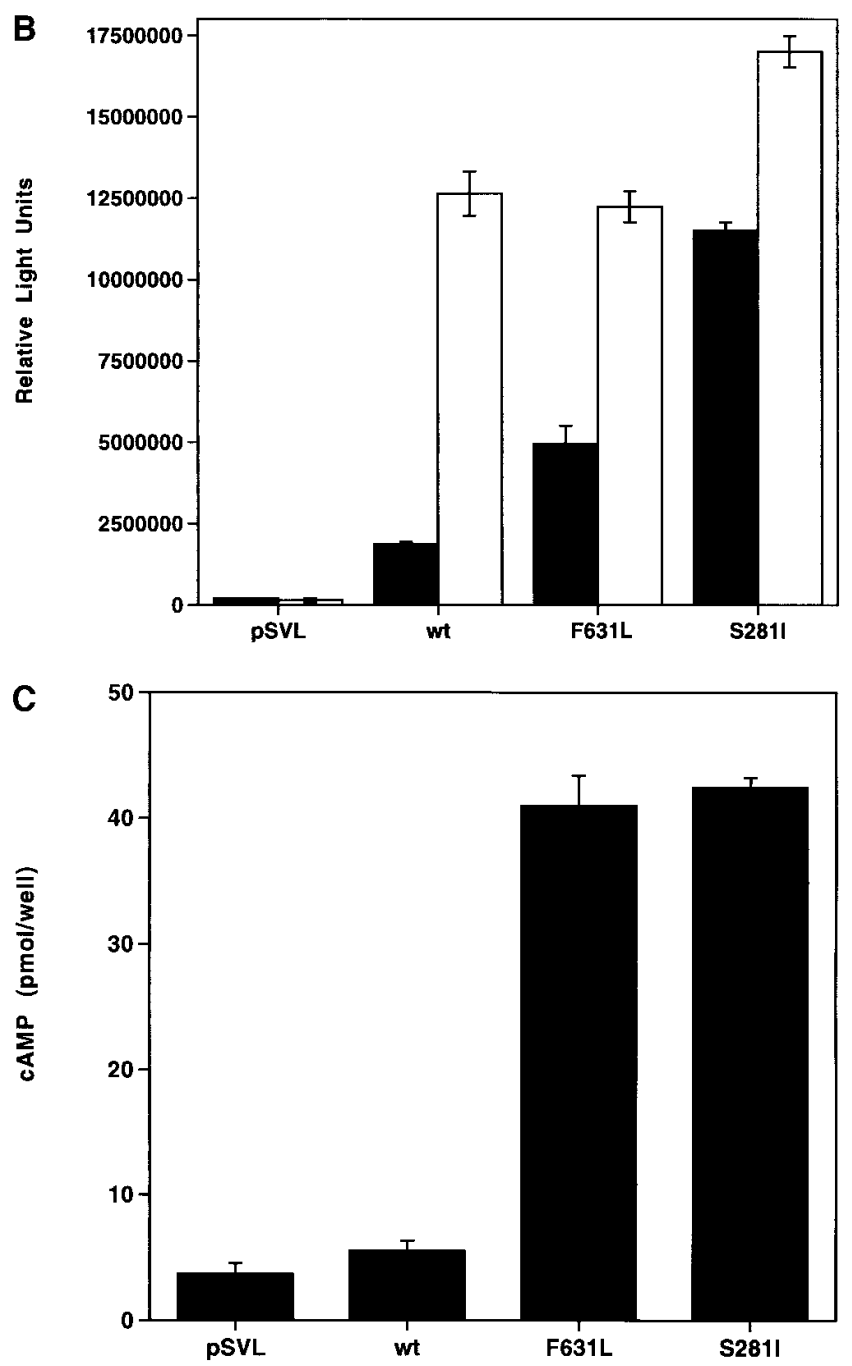

Figure 4. Functional properties of the Ser281 $\rightarrow$ Ile TSH receptor mutation. $(A)$ cAMP-dependent luciferase activity with increasing amounts of DNA constructs. Empty vector $(\bullet)$, wild-type TSH receptor $(\mathbf{O})$, and the mutants Phe $631 \rightarrow$ Leu $(\boldsymbol{\Delta})$, or Ser $281 \rightarrow$ Ile $(\boldsymbol{\nabla})$ were transfected in increasing amounts with a luciferase reporter gene under the control of -846 bp of the glycoprotein $\alpha$ subunit gene which contains two cAMP response elements. Luciferase activity was and TSH-stimulated inositol phosphate accumulation did not differ between the wild type and the mutated receptors (Fig. 5).

TSH binding. Total binding of ${ }^{125}$ I-labeled bovine TSH was measured in transiently transfected TSA cells. The $B_{\max }$ for total TSH binding by the mutant receptor Ser281 $\rightarrow$ Ile was $\sim 45 \%$ lower than that by the wild-type receptor, suggesting a decreased number of surface receptors (Fig. $6 \mathrm{~A}$ ). Consistent with data obtained with other activating mutations (1), Scatchard analysis revealed an increased affinity of the mutant receptor for TSH with a $K_{\mathrm{d}}$ of $\sim 1.7 \times 10^{-9} \mathrm{M}$, in comparison with the wild-type receptor, with a $K_{\mathrm{d}}$ of $\sim 3.82 \times 10^{-9} \mathrm{M}$ (Fig. $6 B$ ).

\section{Discussion}

Constitutive activation of $\mathrm{G}$ protein-coupled receptors forms an important new pathophysiological mechanism (32-34). In the thyroid, somatic mutations in the TSH receptor gene were first demonstrated to be a major molecular cause of hyperfunctioning thyroid adenomas (4). If present in the germline, they lead to nonautoimmune hereditary hyperthyroidism (13, 14), and de novo germline mutations have been found in children with severe congenital hyperthyroidism (15-17).

This neonate with a toxic adenoma illustrates a further, unusual variant of congenital hyperthyroidism. The identification of a somatic mutation suggests that the tumor developed from a single mutated cell, probably as a relatively early event in the development of the thyroid gland, and thus displays a monoclonal composition. Solitary hyperfunctioning thyroid nodules, and congenital hyperthyroidism due to a toxic adenoma in particular, are a very rare cause of hyperthyroidism in infancy and childhood (21-24). Hyperthyroidism in the pediatric population is usually caused by Graves' disease (35). The youngest patient with an autonomous toxic nodule reported to date (a girl of $22 \mathrm{mo}$ ) became overtly hyperthyroid only after administration of iodinated contrast dye (24). The clonal composition of this tumor was determined by $\mathrm{X}$-inactivation analysis and found to be polyclonal, suggesting the presence of a hyperplastic lesion. This contrasts with the findings in this study and the demonstration that the majority of solitary nodules and

measured after $48 \mathrm{~h}$. (ם), Untransfected TSA cells. Values are the means of triplicates \pm SEM. (B) Basal cAMP-dependent luciferase activity $\pm 10 \mathrm{mU} / \mathrm{ml} \mathrm{TSH}$. TSA cells were transfected with $\mathrm{pSVL}$ vector, pSVL-TSH wild-type $(w t)$ receptor, or the mutants Phe631 $\rightarrow$ Leu $(F 631 L)$ or Ser281 $\rightarrow$ Ile $(S 281 I)(0.5 \mu \mathrm{g}$ each) with the calcium-phosphate technique together with a luciferase reporter gene under the control of $-846 \mathrm{bp}$ of the glycoprotein $\alpha$ subunit gene. Luciferase activity was measured after $48 \mathrm{~h}$. The wild-type receptor displays basal constitutive activity in comparison with the empty vector. Relative basal luciferase activity is increased 2.6-fold (Phe631 $\rightarrow$ Leu) and 6.1fold (Ser281 $\rightarrow$ Ile) in comparison with the wild-type receptor (filled columns). Both mutants show a further increase in response to TSH (open columns). Values are the means of triplicates \pm SEM. (C) Basal intracellular cAMP levels. TSA cells were transfected with PSVL vector, pSVL-TSH wild-type receptor, or the mutants Phe631 $\rightarrow$ Leu or Ser281 $\rightarrow$ Ile $(0.5 \mu \mathrm{g}$ each $)$. Basal intracellular cAMP levels were determined by enzyme immunoassay $30 \mathrm{~min}$ after incubation with 0.5 mM 3-iso-butyl-1-methyl-xanthine. Cells transfected with the mutant receptors displayed an approximately eightfold increase of basal cAMP levels in comparison with the wild-type receptor. Values are the means of triplicates \pm SEM. 


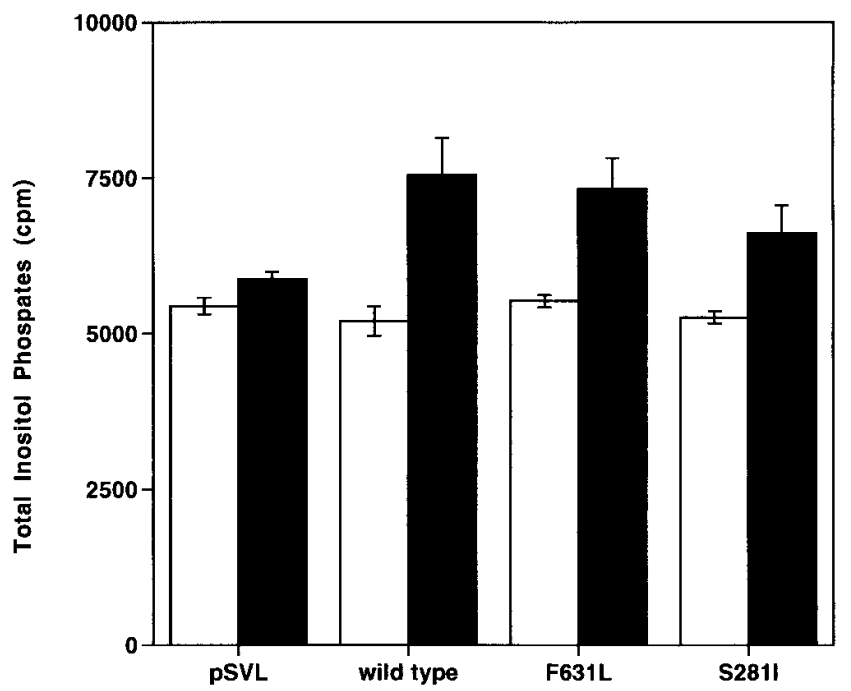

Figure 5. Total inositol phosphates. TSA cells were transfected with pSVL vector, pSVL-TSH wild-type receptor, or the mutants Phe631 $\rightarrow$ Leu $(F 631 L)$ or Ser281 $\rightarrow$ Ile $(S 281 I)(0.5 \mu \mathrm{g}$ each). $24 \mathrm{~h}$ after transfection, cells were treated with $100 \mathrm{mU} / \mathrm{ml} \mathrm{TSH}$ for $30 \mathrm{~min}$. ${ }^{3} \mathrm{H}$-labeled inositol phospates were isolated by AG1-X8 resin chromatography and measured in a scintillation counter. Basal (filled columns) and TSH-stimulated (open columns) inositol phosphate accumulation did not differ between the wild-type and the mutated receptors. Values are the means of triplicates \pm SEM.

nodules from multinodular goiters are of monoclonal origin $(36,37)$.

Besides the unusual finding of a toxic adenoma that causes hyperthyroidism in utero, it is remarkable that the activating mutation, Ser281 $\rightarrow$ Ile, is located in the extracellular domain. To date, naturally occuring activating mutations have been re- ported only in exon 10 of the TSH receptor. They were documented in all extracellular loops, the second and third intracellular loops, and all but the first transmembrane domain, and the still-growing list contains almost twenty different residues $(1,14,16$, and our unpublished results). Supporting our observation, the very same amino acid, serine281, has also been found to be mutated in three toxic adenomas (Gilbert Vassart, personal communication). In these adenomas, the amino substitutions were distinct from the one reported here and resulted in changes from serine to threonine and asparagine.

Mechanistically, these mutations probably result in relief of a negative constraint present in the unliganded wild-type receptor. This concept is supported by in vitro data, suggesting a role for a repressive activity in the carboxy terminus of the extracellular domain. Minimal trypsinization, cleaving residues 354-359 of the extracellular domain, activates the TSH receptor (38). Furthermore, in vitro deletion of residues 339-367 results in a receptor with ligand-independent constitutive activation (39). These data, together with the observation of naturally occurring mutations in the extracellular loops (7), support a model in which the inactive receptor is stabilized by interactions between the carboxy terminus of the extracellular domain and the extracellular loops of the transmembrane domain in the absence of TSH. Relief of this negative constraint, either by the specific ligand TSH or by mutations that destabilize this interaction, could result in activation of the receptor.

The observation of activating mutations in the extracellular portion of the receptor suggests that the mechanisms leading to constitutive activation may be diverse and distinct from mutations in the transmembrane domain or the intracellular loops. Mutations in the transmembrane helices may modify their relative positions and thus mimic the conformational changes induced by binding of ligand, or alter the structure of a domain that inhibits receptor coupling to $G$ proteins in the absence of TSH $(6,13)$.

\section{A}

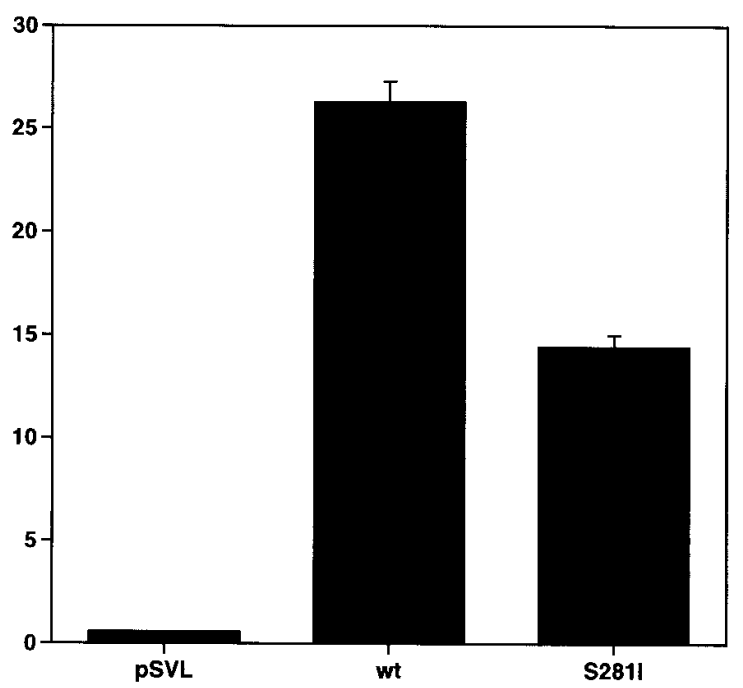

$\mathbf{B}$

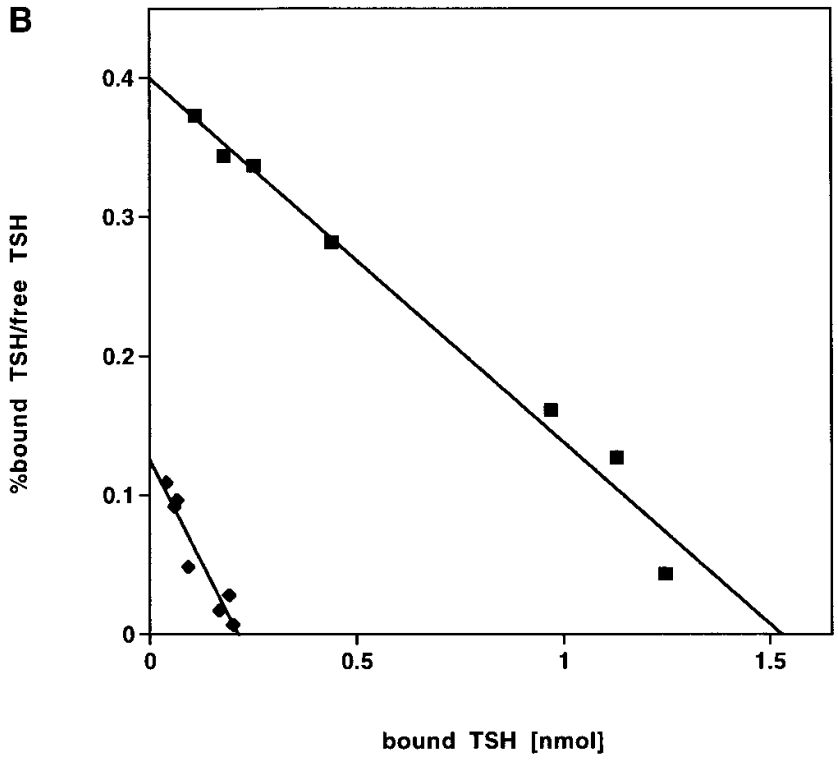

Figure 6. (A) Total TSH binding. Total binding of ${ }^{125}$ I-labeled bovine TSH was measured in transiently transfected TSA cells. $\mathrm{B}_{\mathrm{max}}$ for TSH by the mutant receptor Ser $281 \rightarrow$ Ile is $\sim 45 \%$ lower than with the wild-type receptor, suggesting a decreased number of surface receptors. Values are the means of triplicates \pm SEM. $(B)$ Scatchard analysis of ${ }^{125}$ I-labeled bovine TSH binding to transfected TSA cells. Ser28I $\rightarrow$ Ile $(\diamond)$; wildtype TSH receptor $(\mathbb{\square})$. The mutant has a higher affinity for TSH $\left(K_{\mathrm{d}} \sim 1.7 \times 10^{-9} \mathrm{M}\right)$ in comparison with the wild-type receptor $(3.82 \times$ $\left.10^{-9} \mathrm{M}\right)$. Values are the means of triplicates. 
The continuously growing list of activating mutations of the TSH receptor demonstrates that the affected residues are scattered widely throughout the transmembrane domain and, as shown here, may even occur in the extracellular domain. This indicates that studies of TSH receptor mutations focusing only on restricted segments of the transmembrane domain must be interpreted with caution.

In conclusion, this report illustrates that solitary toxic adenomas may be a cause of congenital hyperthyroidism. Moreover, the identification of an activating somatic mutation in the extracellular domain further expands the broad repertoire of mutations conferring constitutive activity. It also supports the concept that the carboxy-terminal portion of the large extracellular domain plays an important role in the maintenance of a negative constraint.

\section{Acknowledgments}

We are grateful to G. Vassart for sharing his results before publication and providing the pSVL constructs, and BRAHMS Diagnostica $\mathrm{GmbH}$ for providing ${ }^{125} \mathrm{I}$-labeled bovine TSH.

This work was supported in part by the Montreal Children's Hospital Research Institute, National Institutes of Health grant DK42144, and a fellowship grant from the Schweizerische Stiftung für Biologisch-Medizinische Stipendien to P. Kopp.

\section{References}

1. van Sande, J., J. Parma, M. Tonacchera, S. Swillens, J. Dumont, and G. Vassart. 1995. Genetic basis of endocrine disease. Somatic and germline mutations of the TSH receptor in thyroid disease. J. Clin. Endocrinol. Metab. 80: 2577-2585.

2. Vassart, G., and J.E. Dumont. 1992. The thyrotropin receptor and the regulation of thyrocyte function and growth. Endocr. Rev. 13:596-611.

3. Vassart, G., J. Parma, J. van Sande, and J.E. Dumont. 1994. The thyrotropin receptor and the regulation of thyrocyte function and growth: update 1994. Endocr. Rev. 3:77-80.

4. Parma, J., L. Duprez, J. van Sande, P. Cochaux, C. Gervy, J. Mockel, J. Dumont, and G. Vassart. 1993. Somatic mutations in the thyrotropin receptor gene cause hyperfunctioning thyroid adenomas. Nature (Lond.). 356:649-651.

5. Porcellini, A., I. Ciullo, L. Laviola, G. Amabile, G. Fenzi, and V.E. Avvedimento. 1994. Novel mutations of thyrotropin receptor gene in thyroid hyperfunctioning adenomas. J. Clin. Endocrinol. Metab. 79:657-661.

6. Paschke, R., M. Tonacchera, J. van Sande, J. Parma, and G. Vassart. 1994. Identification and functional characterization of two new somatic mutations causing constitutive activation of the thyrotropin receptor in hyperfunctioning autonomous adenomas of the thyroid. J. Clin. Endocrinol. Metab. 79:1785-1789.

7. Parma, J., J. van Sande, S. Swillens, M. Tonacchera, J. Dumont, and G. Vassart. 1995. Somatic mutations causing constitutive activity of the thyrotropin receptor are the major cause of hyperfunctioning thyroid adenomas: identification of additional mutations activating both the cyclic adenosine $3^{\prime}, 5^{\prime}$-monophosphate and inositol phosphate-Ca2+ cascades. Mol. Endocrinol. 9:725-733.

8. Russo, D., F. Arturi, R. Wicker, G.D. Chazenbalk, M. Schlumberger, J.A. DuVillard, B. Caillou, R. Monier, B. Rapoport, S. Filetti, and H.G. Suarez. 1995. Genetic alterations in thyroid hyperfunctioning adenomas. J. Clin. Endocrinol. Metab. 80:1347-1351.

9. Russo, D., F. Arturi, H.G. Suarez, M. Schlumberger, J.A. Du Villard, U. Crocetti, and S. Filetti. 1996. Thyrotropin receptor gene alterations in thyroid hyperfunctioning adenomas. J. Clin. Endocrinol. Metab. 81:1548-1551.

10. Takeshita, A., Y. Nagayama, N. Yokoyama, N. Ishikawa, K. Ito, T. Yamashita, T. Obara, Y. Murakami, K. Kuma, J. Takamatsu, et al. 1995. Rarity of oncogenic mutations in the thyrotropin receptor of autonomously functioning thyroid adenomas. J. Clin. Endocrinol. Metab. 80:2607-2611.

11. Derwahl, M. 1996. TSH receptor and Gs- $\alpha$ gene mutations in the pathogenesis of toxic thyroid adenomas-a note of caution. J. Clin. Endocrinol. Metab. 81:2783-2785.

12. Tonacchera, M., F. Cetani, J. Parma, J. van Sande, G. Vassart, and J. Dumont. 1996. Oncogenic mutations in thyroid adenoma: methodological criteria. Eur. J. Endocrinol. 135:444-446.

13. Duprez, L., J. Parma, J. van Sande, A. Allgeier, J. Leclère, C. Schvartz, M.-J. Delisle, M. Decoulx, J. Orgiazzi, J. Dumont, and G. Vassart. 1994. Germline mutations in the thyrotropin receptor gene cause non-autoimmune autosomal dominant hyperthyroidism. Nat. Genet. 7:396-401.
14. Tonacchera, M., J. van Sande, F. Cetani, S. Swillens, C. Schvartz, P. Winizewski, L. Portmann, J.E. Dumont, G. Vassart, and J. Parma. 1996. Functional characteristics of three new germline mutations of the thyrotropin receptor gene causing autosomal dominant toxic thyroid hyperplasia. J. Clin. Endocrinol. Metab. 81:547-554.

15. Kopp, P., J. van Sande, J. Parma, L. Duprez, H. Gerber, E. Joss, J.L. Jameson, J.E. Dumont, and G. Vassart. 1995. Congenital hyperthyroidism caused by a mutation in the thyrotropin-receptor gene. N. Engl. J. Med. 332: $150-154$.

16. De Roux, N., M. Polak, J. Couet, J. Legher, P. Czernichow, E. Milgrom, and M. Misrahi. 1996. A neomutation of the thyroid-stimulating hormone receptor in a severe neonatal hyperthyroidism. J. Clin. Endocrinol. Metab. 81: 2023-2026.

17. Roe, T., J.L. Jameson, and P. Kopp. 1996. Non-autoimmune neonatal hyperthyroidism due to an activating mutation in the TSH receptor gene. American Association of Pediatrics, Washington 1996. Pediatr. Res. 39:97A. (Abstr.)

18. Zakarija, M., and J.M. McKenzie. 1983. Pregnancy-associated changes in the thyroid-stimulating antibody of Graves' disease and the relationship to neonatal hyperthyroidism. J. Clin. Endocrinol. Metab. 57:1036-1040.

19. Zakarija, M., J.M. McKenzie, and W.H. Hoffmann. 1986. Prediction and therapy of intrauterine and late-onset neonatal hyperthyroidism. J. Clin. Endocrinol. Metab. 62:368-371.

20. Fort, P., F. Lifshitz, M. Pugliese, and I. Klein. 1988. Neonatal thyroid disease: differential expression in three successive offsprings. J. Clin. Endocrinol. Metab. 66:645-647.

21. Popma, B.H., M.D. Cloutier, and A.B. Hayles. 1973. Thyroid nodule producing T3 toxicosis in a child. Mayo Clin. Proc. 48:273-275.

22. Granoff, A.B., and J.M. Hershman. 1977. Suppression of pituitary TSH in a child with a hyperfunctioning thyroid nodule. J. Pediatr. 90:83-85.

23. Fradkin, J.E., and J. Wolff. 1983. Iodide-induced thyrotoxicosis. Medicine (Baltimore). 62:1-20.

24. Namba, H., J.L. Ross, D. Goodman, and J.A. Fagin. 1991. Solitary polyclonal autonomous thyroid nodule: a rare cause of childhood hyperthyroidism. J. Clin. Endocrinol. Metab. 72:1108-1112.

25. Lyons, J., C.A. Landis, G. Harsh, L. Vallar, K. Grünewald, H. Feichtinger, Q.-Y. Duh, O.H. Clark, E. Kawasaki, H.R. Bourne, and F. McCormick. 1990. Two G protein oncogenes in human endocrine tumors. Science (Wash. DC). 249:655-659.

26. De Roux, N., M. Misrahi, N. Chatelain, B. Gross, and E. Milgrom. 1996. Microsatellites and PCR primers for genetic studies and genomic sequencing of the human TSH receptor gene. Mol. Cell. Endocrinol. 117:253-256.

27. Horton, R.M., and L.R. Pease. 1991. Recombination and mutagenesis of DNA sequences using PCR. In Directed Mutagenesis. M. McPherson, editor. IRL Press at Oxford University Press, Oxford. 217-247.

28. Gu, W.X., G.G. Du, P. Kopp, A. Rentoumis, C. Albanese, L.D. Kohn, L.D. Madison, and J.L. Jameson. 1995. The thyrotropin (TSH) receptor transmembrane domain mutation (Pro556-Leu) in the hypothyroid hyt/hyt mouse results in plasma membrane targeting but defective TSH binding. Endocrinology. 136:3146-3153

29. Hirayu, H., R.P. Magnusson, and B. Rapoport. 1985. Studies on the mechanism of desensitization of the cyclic AMP response to TSH stimulation in a cloned rat thyroid cell line. Mol. Cell. Endocrinol. 42:21-27.

30. Berridge, M.J., R.M.C. Dawson, P. Doumer, J.P. Heslop, and R.F. Irvine. 1983. Changes in the levels of inositol phosphates after agonist-dependent hydrolysis of membrane phosphoinositides. J. Biol. Chem. 212:473-482.

31. Kosugi, S., T. Ban, and L.D. Kohn. 1993. Identification of thyroid-stimulating antibody-specific interaction sites in the $\mathrm{N}$-terminal region of the thyrotropin receptor. Mol. Endocrinol. 7:114-130.

32. Lefkowitz, R.J., S. Cotecchia, P. Samama, and T. Costa. 1993. Constitutive activity of receptors coupled to guanine nucleotide regulatory proteins. Trends Pharmacol. Sci. 14:303-307.

33. Shenker, A. 1995. G protein-coupled receptor structure and function: the impact of disease-causing mutations. Baillière's Clin. Endocrinol. Metab. 9:427-451.

34. Spiegel, A.M. 1996. Genetic basis of endocrine disease. Mutations in G proteins and $\mathrm{G}$ protein-coupled receptors in endocrine disease. J. Clin. Endocrinol. Metab. 81:2434-2442.

35. Zimmermann, D., and A.B. Hayles. 1985. Hyperthyroidism in childhood. In Pediatric Thyroidology. F. Delange, D.A. Fisher, and P. Malvaux, editors. S. Karger AG, Basel. 223-239.

36. Namba, H., K. Matsuo, and J.A. Fagin. 1990. Clonal composition of benign and malignant human thyroid tumors. J. Clin. Invest. 86:120-125.

37. Kopp, P., E.T. Kimura, S. Aeschimann, M. Oestreicher, A. Tobler, M.F. Fey, and H. Studer. 1994. Polyclonal and monoclonal thyroid nodules coexist within human multinodular goiters. J. Clin. Endocrinol. Metab. 79:134-139.

38. van Sande, J., C. Massart, S. Costagliola, A. Allgeier, F. Cetani, G. Vassart, and J.E. Dumont. 1996. Specific activation of the thyrotropin receptor by trypsin. Mol. Cell. Endocrinol. 119:161-168.

39. Zhang, M.L., H. Sugawa, S. Kosugi, and T. Mori. 1995. Constitutive activation of the thyrotropin receptor by deletion of a portion of the extracellular domain. Biochem. Biophys. Res. Commun. 211:205-209. 